ARTICLE HISTORY: Received: July 19, 2021 Accepted: August 12, 2021 Published: August 19, 2021

\title{
FACTORS AFFECTING HIGH SCHOOL STUDENTS' DECISION ON CHOOSING A UNIVERSITY: A SURVEY IS CONDUCTED IN THE SOUTHEAST REGION OF VIETNAM
}

\author{
Kieu Lan Huong \\ Postgraduate \\ Department of International business, Faculty of Business Administration \\ Ho Chi Minh City University of Technology (Hutech) \\ Ho Chi Minh city, Vietnam

\begin{abstract}
ФАКТОРЫ, ВЛИЯЮЩИЕ НА РЕШЕНИЕ СТУДЕНТОВ О ВЫБОРЕ ВУЗА: ИССЛЕДОВАНИЕ ПРОВОДИТСЯ В ЮГО-ВОСТОЧНОМ РЕГИОНЕ ВЬЕТНАМА
\end{abstract} \\ Кьеу Лан Хыонг \\ Аспирант \\ Департамент международного бизнеса, факультет деловой администраиии \\ Технологический университет Хошимина (Hutech) \\ Г. Хочимин, Вьетнам
}

\begin{abstract}
Аннотация. Исследование проводится для оценки текущего состояния переменных, влияющих на решение о выборе университета, на основе данных, собранных непосредственно у 574 учеников 12 класса в юговосточном регионе Вьетнама. В этом исследовании применяются метод альфа-коэффициента (альфа Кронбаха), исследовательский факторный анализ (EFA) и многомерная линейная регрессия. Результаты показывают, что пять важных элементов, влияющих на решение о выборе университета, - это возможности трудоустройства в будущем, характеристики университета, усилия по общению со студентами университета, ориентация влиятельных людей, а также разнообразие и привлекательность учебных профессий. Кроме того, в исследовании упоминаются некоторые правила, направленные на улучшение консультирования при зачислении для учащихся 12-х классов в будущем.

Abstract. The study is conducted to assess the current condition of variables influencing a decision on choosing a university via data collected directly from 574 students being grade 12 in the Southeast region of Vietnam. The alpha coefficient method (Cronbach's alpha), exploratory factor analysis (EFA), and multivariate linear regression are applied in this research. The findings indicate that five significant elements affecting the decision on choosing a university are job opportunities in the future, characteristics of the university, efforts to communicate with students of the university, the orientation of influential people, and diversity and attractiveness of training professions. In addition, some policies are also mentioned in the study to enhance enrollment counseling for 12th-grade students in the future.

Ключевые слова: старшеклассники; Университет; Вьетнам, средняя школа, образование во Вьетнаме

Key words: High school students; University; Vietnam, high school, education in Vietnam
\end{abstract}

The training quality and the percentage of graduates having stable jobs are two factors determining the current competitiveness of universities. In that context, the higher education environment is becoming increasingly competitive in training quality, facilities, teaching staff, etc. To gain an advantage in attracting students, schools must first comprehend the elements that impact students' decision on choosing a university, which is the critical point for them to succeed in this competition. In general, most Vietnamese universities are experiencing enrollment difficulties, particularly in implementing the autonomy mechanism under Decree No. 99/2019/ND-CP [13].

Nowadays, learners find choosing the higher education institution that is suitable for their abilities and interests difficult. Some people are unsure of what they want, so their parents decide for them. In addition, there are many references or peers' common trend that is to apply to reputable schools. It is also possible that learners only make a decision based on their emotions. They do not learn and grasp the necessary information about those schools, leading to boredom in studying, quitting their schools, not having a job after graduation, and not being interested in the profession. As a result, choosing a university is a big concern for students and parents. It's also a significant problem for higher education institutions since it affects their existence and development. Therefore, many topics related to this issue have been researched by many authors in Vietnam and around the world.

Due to the above reasons, the author has decided to research a topic named "Factors affecting high school students' decision on choosing a university: a survey is conducted in the Southeast region" to identify and evaluate factors affecting high school students' decision on choosing a university in the Southeast region. The author also makes several recommendations for the planning, enrollment policies, and solutions to attract students to universities. 


\section{Theoretical basis}

Research done by D.W. Chapman (1984) pointed out two groups of elements affecting students' decision on choosing a university, including: (1) Characteristics of student and family (personal and family characteristics) and (2) External influences (influential individuals, fixed characteristics of the university, efforts to communicate with students of the university) [3]. The research model of D.W. Chapman (1984) has been applied by many domestic and foreign researchers such as Cabrera et al. (2000) [2]; Marvin J. Burns (2006) [1]; Cao Hao Thi and Tran Van Qui (2009) [8]; Nguyen Phuong Toan (2011) [10], Nguyen Hoang Minh et al. (2015) [7]. Students' decisions will be influenced by the characteristics of a university (such as its geographic location, tuition, support policies, and living area) [1] [2] [3] [6 ] [7] [8] [10]. Besides, meeting job opportunities after graduation will influence students' decision on choosing university [2] [6] [7] [8] [10] [11] [15]. Furthermore, some elements related to students' characteristics in terms of ability and personal interests significantly influence their decisions. [1] [3] [7] [8] [10] [11].

In addition, advice and persuasion from their friends and family significantly impact their decision on choosing university [1] [3] [4] [7] [10]. Also, the attractiveness of the subject is a factor determining which school will be chosen [1] [3] [7] [10]. Lastly, the popularity and reputation of the school and lecturers are elements contributing to their decisions [1] [7] [9] [10] [15].

Through researches at home and abroad on factors affecting students' decision on choosing a university, the author has built a research model of factors affecting high school students' decision on choosing a university in the Southeast region, including five factors: (1) job opportunities in the future, (2) characteristics of the university, (3) efforts to communicate with students of the university, (4) the orientation of influential people, and (5) diversity and attractiveness of training professions. The above five factors are explained in Table 1 as follows:

Table 1

Interpretation of component variables

\begin{tabular}{|c|c|c|}
\hline No. & Measurement variables & References \\
\hline \multicolumn{3}{|c|}{$\begin{array}{l}\text { JOB OPPORTUNITIES IN THE FUTURE } \\
\end{array}$} \\
\hline 1 & Job opportunities after graduation. & \multirow{4}{*}{$\begin{array}{c}\text { Cabrera \& La Nasa, 2000; Lee \& Chatfield, 2010; Wajeed \& } \\
\text { Micceri, 1997; Tereza, 2013; Thi and Quy, 2007; Nguyen Phuong } \\
\text { Toan, 2011; Nguyen Hoang Minh et al., } 2015 .\end{array}$} \\
\hline 2 & Getting a high income after graduation. & \\
\hline 3 & Having a high status in society. & \\
\hline 4 & $\begin{array}{c}\text { Continuing to study to a higher level in } \\
\text { the future. }\end{array}$ & \\
\hline \multicolumn{3}{|c|}{ CHARACTERISTICS OF THE UNIVERSITY } \\
\hline 5 & $\begin{array}{l}\text { Tuition is low and suitable for family } \\
\text { finances. }\end{array}$ & \multirow{7}{*}{$\begin{array}{l}\text { Chapman, 1984; Thi and Quy, 2007; Nguyen Phuong Toan, 2011; } \\
\text { Lee \& Chatfield, 2010; Canale et al., 1996; Kallio, 1995; Burns, } \\
\text { 2006; Nguyen Hoang Minh et al., 2015. }\end{array}$} \\
\hline 6 & Facilities and equipment are modern. & \\
\hline 7 & $\begin{array}{l}\text { Providing scholarships and preferential } \\
\text { policies for students. }\end{array}$ & \\
\hline 8 & $\begin{array}{l}\text { The geographical location is suitable } \\
\text { and convenient for traveling and } \\
\text { studying. }\end{array}$ & \\
\hline 9 & $\begin{array}{l}\text { There is a dormitory to support } \\
\text { accommodation for students. }\end{array}$ & \\
\hline 10 & The school is famous. & \\
\hline 11 & Lecturers are famous. & \\
\hline \multicolumn{3}{|c|}{ EFFORTS TO COMMUNICATE WITH STUDENTS OF THE UNIVERSITY } \\
\hline 12 & Inviting students to visit the school. & \multirow{6}{*}{$\begin{array}{l}\text { Chapman, 1984; Thi and Quy, 2007; Nguyen Phuong Toan, 2011; } \\
\text { Nguyen Hoang Minh et al., } 2015 .\end{array}$} \\
\hline 13 & $\begin{array}{l}\text { Organizing and guiding enrollment } \\
\text { counseling. }\end{array}$ & \\
\hline 14 & $\begin{array}{l}\text { Finding information on the school's } \\
\text { website. }\end{array}$ & \\
\hline 15 & $\begin{array}{l}\text { Promoting its information on social } \\
\text { media (such as radio and TV). }\end{array}$ & \\
\hline 16 & $\begin{array}{l}\text { Publishing information in newspapers, } \\
\text { magazines, and printed materials. }\end{array}$ & \\
\hline 17 & $\begin{array}{l}\text { Being introduced via career guidance } \\
\text { and counseling programs in high }\end{array}$ & \\
\hline
\end{tabular}




\begin{tabular}{|c|c|c|}
\hline & schools. & \\
\hline \multicolumn{3}{|c|}{ THE ORIENTATION OF INFLUENTIAL PEOPLE } \\
\hline 18 & The influence of family members. & \multirow{5}{*}{$\begin{array}{l}\text { Chapman, 1984; Sabir et al., 2013; Fizer, 2013; Burns, 2006; } \\
\text { Nguyen Phuong Toan, 2011; Nguyen Hoang Minh et al., } 2015 .\end{array}$} \\
\hline 19 & The impact of friends. & \\
\hline 20 & Advice from teachers. & \\
\hline 21 & $\begin{array}{l}\text { The impact of relatives and friends who } \\
\text { are studying here. }\end{array}$ & \\
\hline 22 & $\begin{array}{l}\text { Activities associated with career } \\
\text { guidance and counseling programs of } \\
\text { the university. }\end{array}$ & \\
\hline \multicolumn{3}{|c|}{ DIVERSITY AND ATTRACTIVENESS OF TRAINING PROFESSIONS } \\
\hline 23 & Training professions are diverse. & \multirow{4}{*}{$\begin{array}{c}\text { Burns, 2006; Nguyen Phuong Toan, 2011; Cabrera et al., 2000; } \\
\text { Nguyen Hoang Minh et al., } 2015 .\end{array}$} \\
\hline 24 & The training major is interesting. & \\
\hline 25 & $\begin{array}{l}\text { The training major is suitable for } \\
\text { individual interests. }\end{array}$ & \\
\hline 26 & $\begin{array}{l}\text { The training major is suitable for } \\
\text { students' ability. }\end{array}$ & \\
\hline
\end{tabular}

\section{Research Methods}

\subsection{Research model}

Based on theoretical models and empirical research hypotheses, a model of the main factors which affect high school students' decision on choosing a university in the Southeast region is proposed, as follows:

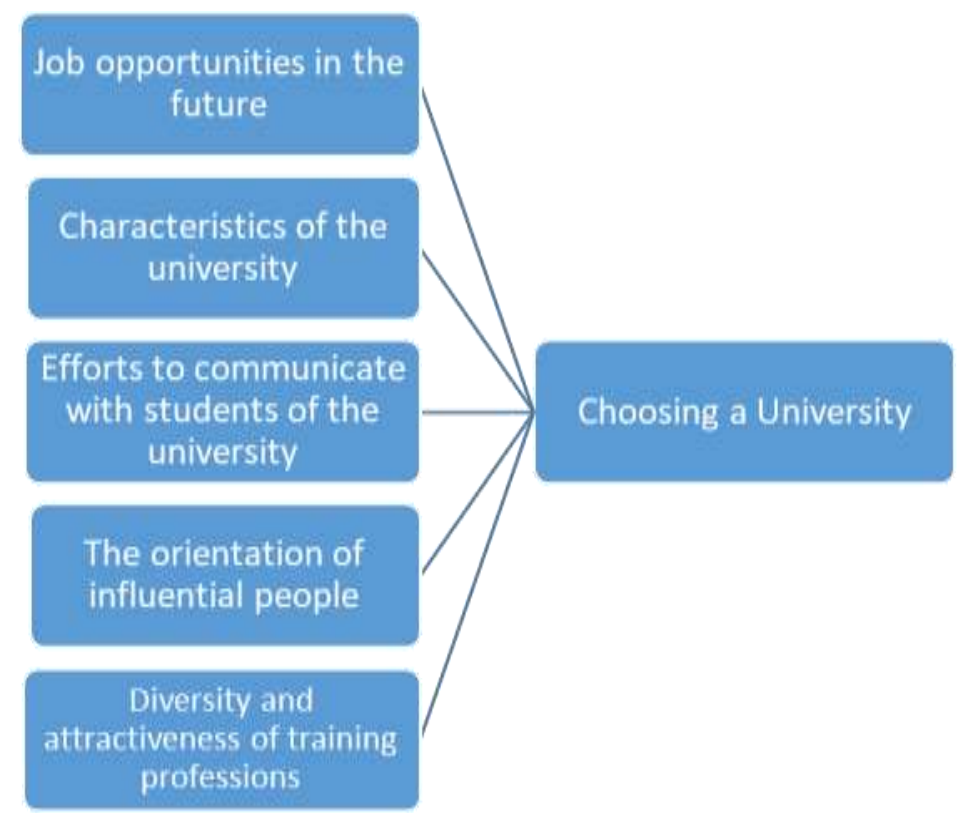

Figure 1. Model of factors affecting students' decision on choosing a niversity

\subsection{The method of data collection}

Research subjects are students studying in grade 12 at high schools in the Southeast region. Data was collected by convenience sampling from February 2021 to April 2021. Hair et al. (1987) recommended that the sample size for the exploratory factor analysis (EFA) was at least 50, preferably 100. The ratio of observed variables and the measurement variables is 5:1, which means that every measurement variable requires at least five observed variables [5]. In the exploratory factor analysis model, there are 27 variables used to measure the factors influencing students' decision on choosing a university in the Southeast region. As a result, the sample size must be at least 130 observed variables $(26 \times 5$ =130). However, the author has suggested a sample size of 300 to achieve high overall representativeness.

\subsection{Data analysis method}

In this study, the author uses a method to test the scale affecting high school students' decision on choosing a university in the Southeast region by Cronbach's Alpha coefficient, exploratory factor analysis (EFA), and multivariate 
regression (in which variable $\mathrm{Y}$ is students' decision using a 5-point Likert scale). The author has used the Likert scale with scores ranging from 1 (strongly disagree) to 5 (strongly agree) to measure observed variables.

\section{Research results}

\subsection{Characteristics of the survey sample to test the reliability of scales by Cronbach's Alpha}

The survey samples were chosen by stratified random sampling. The participants are 12th-grade students at high schools in the Southeast region. The components of this scale reach high Cronbach's alpha coefficients. Specifically, Cronbach's alpha coefficient of job opportunities in the future is 0.800 . Characteristics of the university have Cronbach's alpha coefficient of 0.792. Cronbach's alpha coefficient of efforts to communicate with students of the university is 0.884 . Cronbach's alpha coefficient of the orientation of influential people is 0.900 . Finally, the diversity and attractiveness of training professions have Cronbach's alpha coefficient of 0.895 . Furthermore, most of the corrected item-total correlation is greater than 0.4 , which means that the corrected item-total correlation is satisfactory. Therefore, all the component variables will be included in the following exploratory factor analysis (EFA).

\subsection{Evaluating the scale by the exploratory factor analysis (EFA)}

Table 2

The results of the exploratory factor analysis (EFA)

\begin{tabular}{|c|c|c|c|c|c|}
\hline \multirow{2}{*}{$\begin{array}{l}\text { Observed } \\
\text { variables }\end{array}$} & \multicolumn{5}{|c|}{ Elements } \\
\hline & 1 & 2 & 3 & 4 & 5 \\
\hline GT1 & .824 & & & & \\
\hline GT2 & .816 & & & & \\
\hline GT3 & .776 & & & & \\
\hline GT4 & .764 & & & & \\
\hline GT6 & .761 & & & & \\
\hline GT5 & .755 & & & & \\
\hline $\mathrm{DH} 2$ & & .859 & & & \\
\hline DH1 & & .841 & & & \\
\hline DH3 & & .815 & & & \\
\hline DH5 & & .812 & & & \\
\hline DH4 & & .800 & & & \\
\hline DD7 & & & .755 & & \\
\hline DD6 & & & .718 & & \\
\hline DD2 & & & .659 & & \\
\hline DD4 & & & .627 & & \\
\hline DD5 & & & .604 & & \\
\hline DD3 & & & .560 & & \\
\hline DD1 & & & .558 & & \\
\hline HD1 & & & & .877 & \\
\hline HD3 & & & & .874 & \\
\hline HD4 & & & & .867 & \\
\hline HD2 & & & & .865 & \\
\hline $\mathrm{CH} 2$ & & & & & .824 \\
\hline $\mathrm{CH} 3$ & & & & & .796 \\
\hline $\mathrm{CH} 1$ & & & & & .786 \\
\hline $\mathrm{CH} 4$ & & & & & .697 \\
\hline \multicolumn{6}{|c|}{$\begin{array}{l}\text { Extraction Method: Principal Component Analysis. } \\
\text { Rotation Method: Varimax with Kaiser Normalization. }\end{array}$} \\
\hline & & cet & in 5 it & & \\
\hline
\end{tabular}

The results of the KMO \& Bartlett's test in the factor analysis indicate that the KMO coefficient is quite high $(\mathrm{KMO}=0.814>0.5)$, which proves that the variables included in the exploratory factor analysis (EFA) are significant. Thus, the analytical model is consistent with the proposed hypotheses.

Next, Bartlett's test of sphericity has a value close to 0 (Sig. $=0.000<0.05$ ). This value rejects hypothesis $\mathrm{H} 0$ that assumes that the variables are not correlated with each other. It also demonstrates that the data used for factor analysis are completely appropriate in this study. 
The cumulative of variance is $62.134 \%$ (> 50\%), which meets the requirements and indicates that the component variables explains $62.134 \%$ of the variability of the data shown in the following five factors: F1: job opportunities in the future, F2: characteristics of the university, F3: efforts to communicate with students of the university, F4: the orientation of influential people, and F5: diversity and attractiveness of training professions.

\subsection{Multiple Linear Regression}

Choosing a university by high school students in the Southeast region is influenced by many factors, including internal and external factors. Therefore, it's crucial for us to use econometric models to determine their influence scientifically.

Based on the multiple regression model built in the theoretical basis and the SPSS Statistics software to support the analysis, the author has obtained the following findings: 
Table 3

Results of multiple linear regression analysis

\begin{tabular}{|c|c|c|c|c|c|c|c|c|}
\hline & \multirow{2}{*}{ Model } & \multicolumn{2}{|c|}{$\begin{array}{l}\text { Unstandardized } \\
\text { Coefficients }\end{array}$} & \multirow{2}{*}{$\begin{array}{c}\text { Standardized } \\
\text { Coefficients }\end{array}$} & \multirow{2}{*}{$\mathrm{t}$} & \multirow{2}{*}{ Sig. } & \multicolumn{2}{|c|}{ Collinearity Statistics } \\
\hline & & $\mathrm{B}$ & Std. Error & & & & Tolerance & VIF \\
\hline \multirow{6}{*}{1} & (Constant) & 1.132 & .086 & & 13.214 & .000 & & \\
\hline & $\mathrm{MCH}$ & .041 & .012 & .088 & 3.522 & .000 & .898 & 1.113 \\
\hline & MDD & .381 & .023 & .454 & 16.533 & .000 & .735 & 1.360 \\
\hline & MGT & .179 & .011 & .400 & 16.017 & .000 & .890 & 1.124 \\
\hline & $\mathrm{MDH}$ & .075 & .008 & .225 & 8.813 & .000 & .853 & 1.172 \\
\hline & MHD & .029 & .010 & .066 & 2.792 & .005 & .990 & 1.010 \\
\hline \multicolumn{7}{|c|}{ Coefficient of determination $\mathrm{R}^{2}$} & \multicolumn{2}{|c|}{0.685} \\
\hline \multicolumn{7}{|c|}{ Adjusted $\mathrm{R}^{2}$} & \multicolumn{2}{|c|}{0.682} \\
\hline \multicolumn{7}{|c|}{ Sig.F } & \multicolumn{2}{|c|}{0.000} \\
\hline \multicolumn{7}{|c|}{ Durbin-Watson statistic } & \multicolumn{2}{|c|}{1.614} \\
\hline
\end{tabular}

Table 4 reveals that the Sig.F of the model is 0.000 , much smaller than the significant at the $1 \%$, so the regression model is statistically significant, usable, and suitable for the data set. It means that independent variables affect the dependent variable Y (selecting university). The adjusted R - squared is $68.2 \%$, which means that factors included in the model will explain $68.2 \%$ of the variation in choosing universities and colleges. The Durbin-Watson statistic of the model is 1.614, showing that the model does not have autocorrelation [12]. Besides, the variance inflation factor (VIF) of the variables in this model is less than 10, so it can be concluded that there is no multicollinearity among the variables [12].

The analysis results also demonstrate that five variables such as job opportunities in the future $(\mathrm{CH})$, characteristics of the university (DD), efforts to communicate with students of the university (GT), the orientation of influential people (DH), and diversity and attractiveness of training professions (HD) possess the statistical significance of $1 \%$.

\section{Conclusion}

Although the study has significant limitations due to the small sample size and the fact that the participants are only high school students in the Southeast area, it has developed a model for selecting higher education institutions for Vietnamese high school students. Five factors affecting their decision have been identified, including job opportunities in the future $(\mathrm{CH})$, characteristics of the university (DD), efforts to communicate with students of the university (GT), the orientation of influential people (DH), and diversity and attractiveness of training professions (HD).

In the complicated developments of the COVID-19 pandemic, the findings become more meaningful. It is critical for universities to implement strategies for promoting communication and attracting learners. This study has provided students and their parents with helpful information such as employment criteria and personal suitability. It also helps them understand that an institution with good facilities will make them satisfied (or happy) in the learning process. Although external influences are minor, students should consult and seek advice from people around, especially older students, because this is still a reliable source of information.

Based on the results, the author would like to make some recommendations as follows:

Firstly, the Department of Education and Training needs to review and create statistics on the number of graduates of each school who have suitable jobs, which will be a basis for high school students to consider and decide. It should increase contact with students' parents, guide and recommend reputable and high-quality colleges so that parents can make an impact on their children.

Secondly, teachers, especially homeroom teachers, need to learn and master information about universities' standards and curriculum and job opportunities through alumni to help 12th- grade students. Besides, high schools should invite alumni who have gained many achievements to participate in activities associated with career guidance and counseling programs for students because specific actions and actual people will be the most convincing evidence. These things will have a significant impact on selecting colleges of students.

Thirdly, universities need to give successful examples who have attended there and are successful in society, helping students feel confident and secure when making a decision. In addition, they should link to higher education programs to meet the needs of learners. Moreover, they need to create a youthful and dynamic image and build a team of dedicated, qualified, and reputable lecturers. Thanks to that, students will ultimately trust the knowledge imparted by these teachers and decide to study at these universities.

Fourthly, universities should organize career guidance and counseling programs for students and their parents because the influence of family and relatives also plays a vital role in their decision on choosing a university. Besides, they shall commit to and expand the scholarships and the tuition exemption/reduction policy for some cases other than those under current regulations. The higher the scholarships are, the more they stimulate the students to strive. Likewise, 
the more the tuition exemption/reduction policy is, the more it reduces the financial burden for students and their families. Therefore, all of the above policies will affect students' decisions on choosing a higher education institution.

Lastly, increasing the number of enrollments for the professions that society requires is important. It's clear that if a higher education institution has more enrollment quotas, more students will enroll. Furthermore, universities should regularly conduct surveys to determine the factors affecting students in each province to have an orientation suitable to their individual characteristics. Thus, they can create suitable activities associated with career guidance and bring the desired results.

References
1. Burns M. J. Factors influencing the college choice of African-American students admitted to the college of agriculture, food and natural resources. Athesis presented to the Faculty of the Graduate School. University of MissouriColumbia, USA, 2006.

2. Cabrera, A. F. \& La Nasa, S. M. Understanding the College choice of Disadvantaged Students: New Directions for Institutional Research. No.107. San Francisco: Jossey-Bass, 2000.

3. Chapman, D. W.. A model of student college choice // The Journal of Higher Education. 1981. Vol.52, No.5. Pp. 490-505.

4. Fizer. D. Factors Affecting Career Choices of College Students Enrolled in Agriculture. A Research Paper Presented for the Master of Science in Agriculture and Natural Resources Degree, The University of Tennesssee, Martin, 2013.

5. Hair, J. S., Anderson, R. E., \& Tatham, R. L. Multivariate data analysis with readings. New York: Macmillan, 1987.

6. Lee, S. J.\& Chatfield, H. K. The analysis of Factors affecting choice of college: A case study of UNLV hotel College students. William F. Harrah College of Hotel Administration University of Nevada Las Vegas, 2010.

7. Minh, Nguyen Hoang \& Ut, Luong Van \& Khanh, Le Truong \& Khoa, Tran Dang \& Thang, Nguyen Minh. Research on factors affecting the 12th-grade students' decision on choosing a university in high schools in Vinh Long City. Vinh Long City: Scientific project of Cuu Long University, 2015.

8. Qui, Tran Van \& Thi, Cao Hao. Factors affecting the high school students' decision on choosing a university // Science and Technology Magazine. 2009. Vol. 12. Issue 15. Pp. 87-102.

9. Sabir R. I., Ahmad. W., Ashraf R. U.,\& Ahmad N. Factors Affecting University And Course Choice: A Comparison of Un-dergraduate Engineering and Business Students in Central Punjab, Pakistan // Journal of Basic and Applied Scientific Research. 2013. No. 10. Pp 298-305.

10. Toan, Nguyen Phuong. Survey on factors affecting the 12th-grade students' decision on choosing a university in Tien Giang Province. Hanoi: Master thesis, Vietnam National University, 2011.

11. Tereza, N. Analysis and Comparison of Factors influencing University choice // Journal of Competitiveness. 2013. Vol. 5, Issue 3. Pp. 90-100.

12. Trong, Hoang \& Ngoc, Chu Nguyen Mong. Research data analysis with SPSS. Ho Chi Minh City: Hong Duc Publishing House, 2008.

13. Vietnam Prime Minister. Decree No. 99/2019/ND-CP of the Government on detailing and guiding the implementation of a number of Articles of the Law amending and supplementing a number of Articles of the Law on Higher Education, 2020.

14. Worldometer. Coronavirus Updates, 2020. Url: https://www.worldometers.info/coronavirus/.

15. Wajeeh, E., Micceri, T. Institutional factors affecting student enrollment at the University of South Florida Office of Institutional Research and Planning. USF., Tampa: Florida, 1996. 